\begin{tabular}{|l|l|l|l|}
\hline DEC $212000(20)$ & ENGINEERING DATA TRANSMITTAL & Pao 1 of 1 \\
\hline
\end{tabular}

\begin{tabular}{|c|c|c|c|c|c|c|c|c|}
\hline \multicolumn{3}{|c|}{$\begin{array}{l}\text { 2. To: (Receiving Organization) } \\
\text { DISTRIBUTION }\end{array}$} & \multicolumn{3}{|c|}{$\begin{array}{l}\text { 3. From: (Originating Organization) } \\
\text { Information Resource \& Records } \\
\text { Management }\end{array}$} & \multicolumn{3}{|c|}{ N/A } \\
\hline \multicolumn{3}{|c|}{ 5. Proj./Prog./Dept./Div.: } & \multicolumn{3}{|c|}{$\begin{array}{l}\text { 6. Design Authority/ Design Agent/Cog. } \\
\text { Engr.: }\end{array}$} & \multicolumn{3}{|c|}{ 7. Purchase Order No.: } \\
\hline \multicolumn{6}{|c|}{ 8. Originator Remarks: } & \multirow{2}{*}{\multicolumn{3}{|c|}{$\begin{array}{l}\text { 9. Equip./Component No.: } \\
\text { N/A }\end{array}$}} \\
\hline \multirow{2}{*}{\multicolumn{6}{|c|}{$\begin{array}{l}\text { ATTACHED IS THE COMPLETED TANK FARM OPERATIONS SURVEILLANCE } \\
\text { AUTOMATION ANALYSIS DOCUMENT. }\end{array}$}} & & & \\
\hline & & & & & & \multicolumn{3}{|c|}{$\begin{array}{l}\text { 10. System/Bldg./Facility: } \\
\text { N/A }\end{array}$} \\
\hline \multirow{3}{*}{\multicolumn{3}{|c|}{ 11. Receiver Remarks: }} & e Docu & t? [] Yes $[\mathrm{X}]$ No & & \multicolumn{3}{|c|}{$\begin{array}{l}\text { 12. Major Assm. Dwg. No.: } \\
\text { N/A }\end{array}$} \\
\hline & & & & & & \multicolumn{3}{|c|}{$\begin{array}{l}\text { 13. Permit/Permit Application No.: } \\
\text { N/A }\end{array}$} \\
\hline & & & & & & \multicolumn{3}{|c|}{$\begin{array}{l}\text { 14. Required Response Date: } \\
\text { N/A }\end{array}$} \\
\hline \multicolumn{5}{|c|}{ DATA TRANSMITTED } & (F) & (G) & (H) & (I) \\
\hline $\begin{array}{l}\text { (A) } \\
\text { ltem } \\
\text { No. }\end{array}$ & (8) Documentidrawing No. & $\begin{array}{l}\text { (C) } \\
\text { Sheot } \\
\text { No. }\end{array}$ & $\begin{array}{l}\text { (D) } \\
\text { Rev. } \\
\text { No. }\end{array}$ & (E) Title or Description of Data Transmitted & $\begin{array}{l}\text { Approval } \\
\text { Desig- } \\
\text { nator }\end{array}$ & $\begin{array}{l}\text { Reason for } \\
\text { Trans- } \\
\text { mittal }\end{array}$ & $\begin{array}{l}\text { Origi- } \\
\text { Nator } \\
\text { Dispo- } \\
\text { Shion }\end{array}$ & $\begin{array}{l}\text { Rocoiver } \\
\text { Dispo- } \\
\text { Sition }\end{array}$ \\
\hline 1 & RPP-7521 & $\mathrm{N} / \mathrm{A}$ & 0 & $\begin{array}{l}\text { Tank Farm Operations } \\
\text { Surveillance Automation Analysis }\end{array}$ & N/A & 2 & 2 & 1 \\
\hline & & & & & & & & \\
\hline & & & & & & & & \\
\hline & & & & & & & & \\
\hline & & & & & & & & \\
\hline & & & & & & & & \\
\hline
\end{tabular}

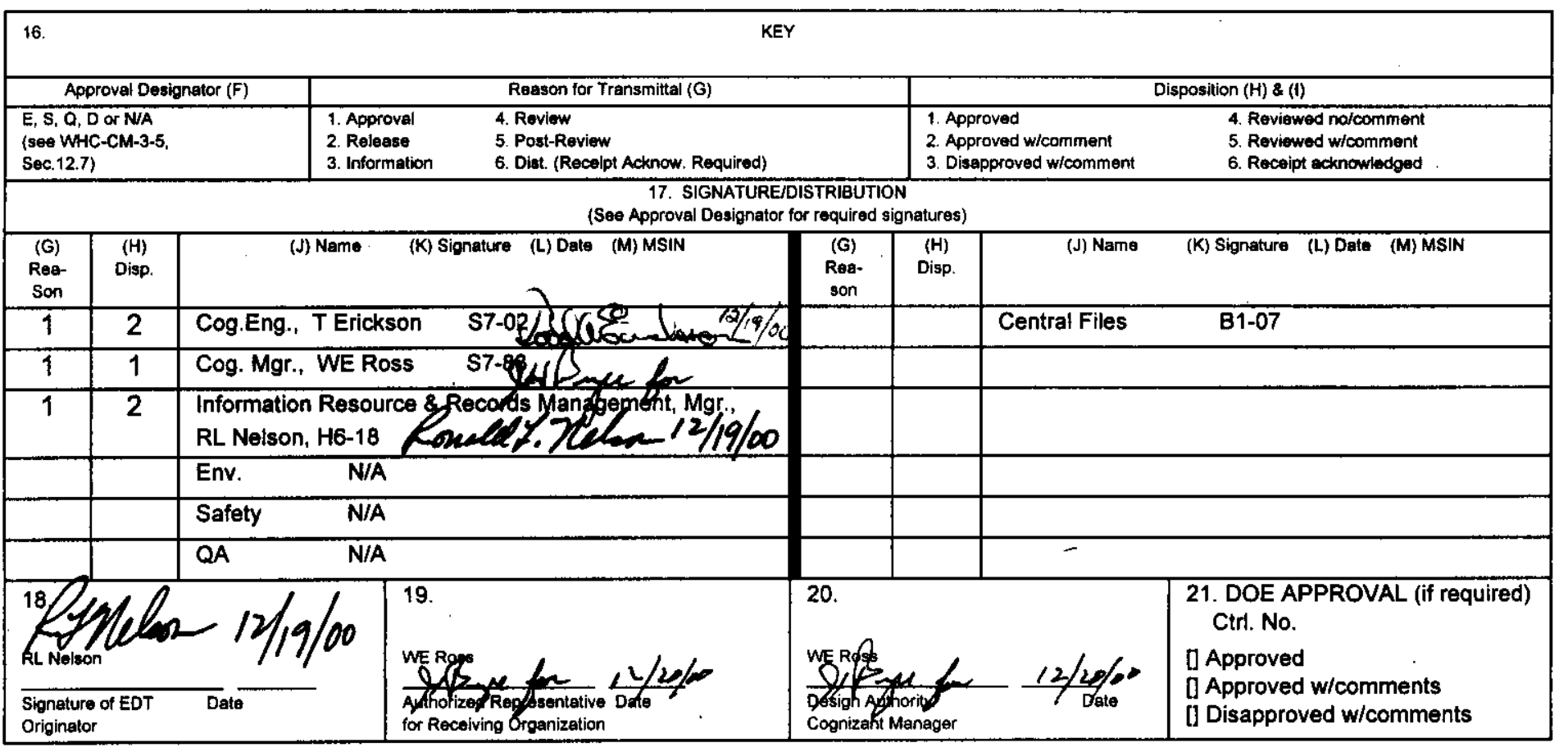




\section{DISTRIBUTION SHEET}

\begin{tabular}{|c|c|c|c|c|c|c|}
\hline \multirow{2}{*}{\multicolumn{2}{|c|}{$\begin{array}{l}\text { To } \\
\text { Distribution }\end{array}$}} & \multirow{2}{*}{\multicolumn{3}{|c|}{$\begin{array}{l}\text { From } \\
\text { Information Resource \& Records } \\
\text { Management }\end{array}$}} & \multicolumn{2}{|l|}{ Page 1 of 1} \\
\hline & & & & & \multicolumn{2}{|c|}{ Date December 19, 2000} \\
\hline \multirow{2}{*}{\multicolumn{5}{|c|}{$\begin{array}{l}\text { Project Title } M \text { Work Order } \\
\text { Tank Farm Operations Surveillance Automation Analysis Document }\end{array}$}} & \multicolumn{2}{|c|}{ EDT No. 628578} \\
\hline & & & & & \multicolumn{2}{|l|}{ ECN No. N/A } \\
\hline & Name & MSIN & $\begin{array}{l}\text { Text } \\
\text { With All } \\
\text { Attach. }\end{array}$ & $\begin{array}{l}\text { Text } \\
\text { Only }\end{array}$ & $\begin{array}{l}\text { Attach./ } \\
\text { Appendix } \\
\text { Only }\end{array}$ & $\begin{array}{l}\text { EDT/ECN } \\
\text { Only }\end{array}$ \\
\hline Central Files & & B $1-07$ & $x$ & & & \\
\hline $\begin{array}{l}\text { J. H. Bryce } \\
\text { K. A. Crace } \\
\text { T. Erickson } \\
\text { P. B. Isaacs } \\
\text { D. L. Marquez } \\
\text { R. L. Nelson } \\
\text { W. E. Ross }\end{array}$ & $\begin{array}{l}(\mathrm{H}) \\
(\mathrm{H})\end{array}$ & $\begin{array}{l}\text { S7-83 } \\
\text { G3-37 } \\
\text { S7-02 } \\
\text { H8-41 } \\
H 6-18 \\
\text { H6-18 } \\
\text { S7-83 }\end{array}$ & $\begin{array}{l}x \\
x \\
x \\
x \\
x\end{array}$ & & & $x$ \\
\hline
\end{tabular}




\title{
Tank Farm Operations Surveillance Automation Analysis
}

\author{
K. A. Crace and D. L. Marquez \\ CH2M HILL Hanford Group, Inc., Richland, Washington 99352 \\ U.S. Department of Energy Contract DE-AC06-99RL14047
}

\author{
EDT/ECN: EDT 628578 \\ UC: UC2000 \\ Org Code: 7A100 \\ B\&R Code: N/A \\ Charge Code: 102613 / AJ60 HFCH032l \\ Total Pages: $22, \mu / 2 / 21$
}

Key Words: Field Data Collection, Field Operator, Operator Rounds.

Abstract: The Nuclear Operations Project Services identified the need to improve manual tank farm surveillance data collection, review, distribution and storage practices often referred to as Operator Rounds. This document provides the analysis in terms of feasibility to improve the manual data collection methods by using handheld computer units, barcode technology, a database for storage and acquisitions, associated software, and operational procedures to increase the efficiency of Operator Rounds associated with surveillance activities.

\footnotetext{
TRADEMÁRK DISCLAIMER. Reference herein to any specific commercial product, process, or service by trade name, trademark, manufacturer, or otherwise, does not necessarily constitute or imply its endorsement, recomendation, or favoring by the United States Government or any agency thereof or its contractors or subcontractors.

Printed in the United States of America. To obtain copies of this document, contact: Document Control Services, P.O. Box 950, Mailstop H6-0B, Richland WA 99352, Phone (509) $372-2420 ; \operatorname{Fax}(509) 376-4989$.
}

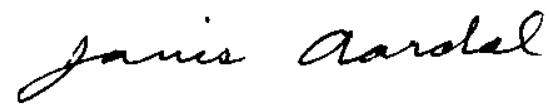

Release Approval

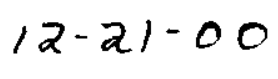

Date

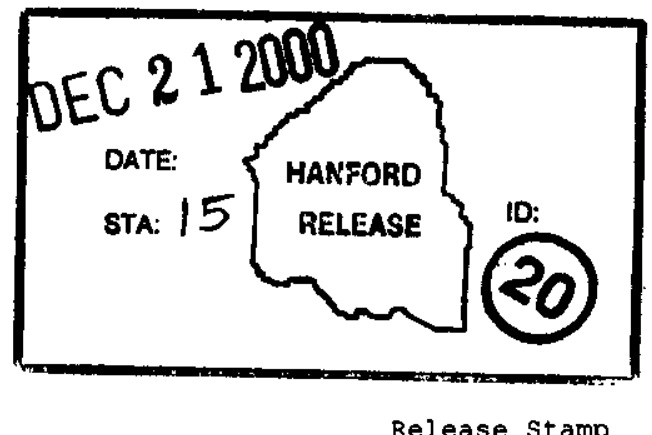

Release stamp 


\section{TANK FARM OPERATIONS SURVEILLANCE AUTOMATION \\ ANALYSIS}

Prepared for

CH2M HILL Hanford Group, Inc. 


\section{TABLE OF CONTENTS}

Section

Page

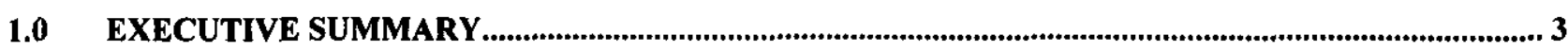

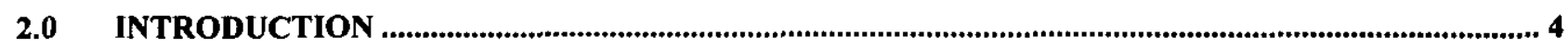

2.1 Scope

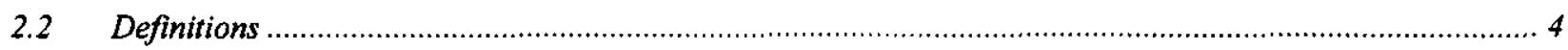

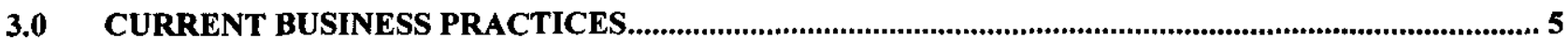

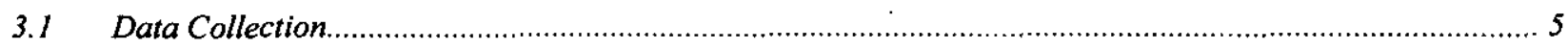

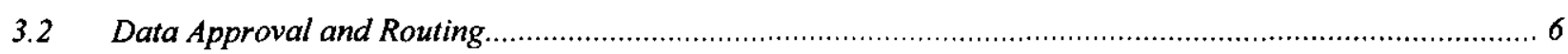

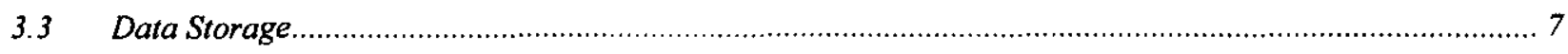

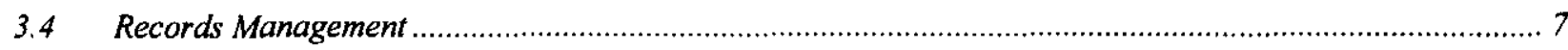

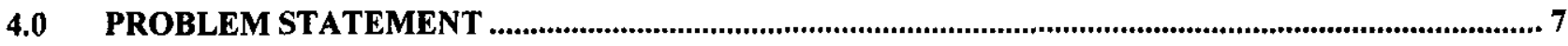

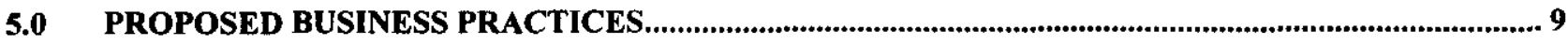

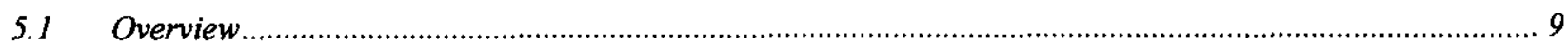

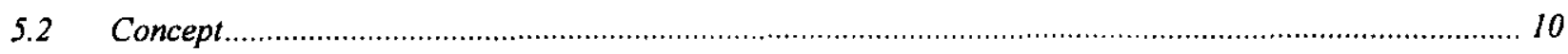

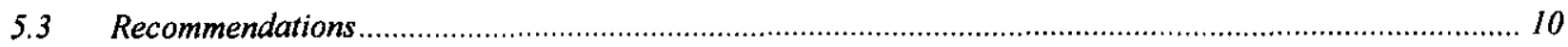

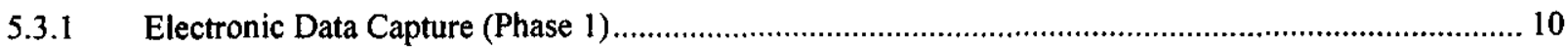

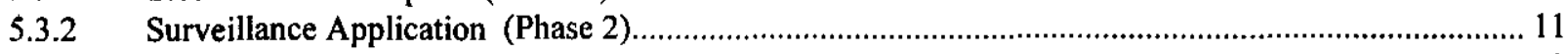

5.3.3 Wireless \& Work Management Integration (Phase 3) ................................................................... 12

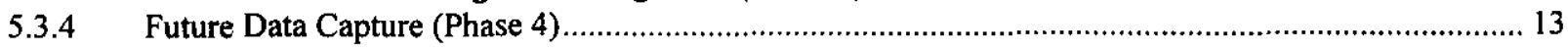

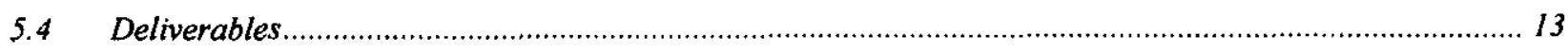

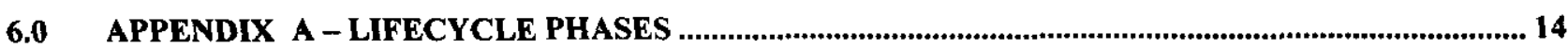

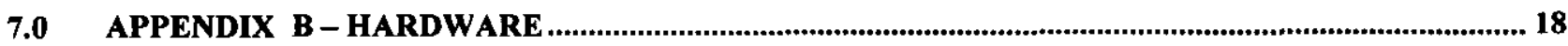




\subsection{EXECUTIVE SUMMARY}

Nuclear Operations Project Services identified the need to improve manual tank farm surveillance data collection, review, distribution and storage practices often referred to as Operator Rounds.

The overall concept to improve the manual method is to use handheld computer units, barcode technology, a database for storage and acquisitions, associated software, and operational procedures to increase the efficiency of Operator Rounds associated with surveillance activities and increase the usefulness of the data collected. The automation discussed throughout the document includes: elimination of Operator Rounds data sheets, on-the-spot baseline criteria data checking, reduction of rechecks, elimination of transcription errors during data input, provide shift supervisors methods to review data, perform trending, analyze equipment failures, and data anomalies. The Integrated Environment, Safety and Health Management System (ISMS) guiding principle of worker involvement warrants Field Operators participation in all aspects of the project.

To complete this study, a review of a similar project was evaluated. The project, Handheld Data Acquisition for Tank Farms (HDAT) was used in the early 90 's. HDAT used handheld computer units that supported barcode technology to collect tank temperature readings. Although the project was well received, the technology of the handheld computer units proved not to be sufficient for daily use. Now that hardware technology has advanced, the overall concept and use of an application like HDAT is more feasible. The findings of this study recommend a phased approach utilizing electronic data collection and management tools.

For the purposes of this analysis several people were interviewed for their perspective and ideas on this subject. Their responses were positive. Organizations and services included:

- Nuclear Operations Project Services (operations and management personnel)

- Data Evaluation Group

- Technical Data Services

- DST Engineering

- Interim Stabilization

During the interview process, two main areas that require management decisions were identified. These include the records keeping requirement storage practices and the future expansion of current data acquisition systems.

- The Tank Monitoring and Control System (TMACS) is a candidate to collect some of these surveillance data that are collected manually. If so, what equipment, cost, and plans to expand are scheduled for the upcoming years? What criteria will be used to decide if TMACS should collect the reading? Other options are available.

- $\quad$ A decision to use an electronic signature should be considered and could be handled with user security. At this time, the requirements states that Operator Rounds data sheets will be signed by those who collected and approved the data and kept at the facility for five years. The hard copy is required for signature and record purposes. If electronic signature and a database were to be considered, then the requirements would have to be challenged. 


\subsection{INTRODUCTION}

This document reviews current business processes and recommends improvements for manual tank farm surveillance data collection, review, distribution and storage practices often referred to as Operator Rounds. Operator Rounds are performed by the Nuclear Operations Project Services at CH2M HILL Hanford Group, Inc. (CHG) in the 200 east and west area tank farms located at the Hanford site. The problem statement is discussed later.

A large percentage of tank farm surveillance data are manually collected on Operator Rounds data sheets on a daily, weekly, monthly, and quarterly basis. These Operator Rounds data sheets collected require daily review, database input (for some data types), distribution of the data sheets, and short and long-term storage. A smaller percentage of tank farm surveillance data are collected by a data acquisition system called Tank Monitoring and Control System. In some cases, data are captured manually and by TMACS and the information is entered multiple times in different data systems. This is counter to the CHG Chief Information Officer's objective; enter data only once. In addition, other non-surveillance data and checks are collected using Operator Rounds data sheets. These items must be accounted for in any effort to automate surveillance activities.

Recently, a study was performed to ensure that the data being collected are required. The original study was conducted in July 1999 by Management Strategies, Inc. and is referred to as the "Requirements Based Review of Operations Surveillance at the River Protection Project". The follow up to this study is on going and is part of the 2X Productivity Program.

This document satisfies the Hanford Site's requirements, IRM Application Software System Life Cycle Standards, HNF-PRO-2778, rev. 0, to ensure that a study is formally documented prior to definition/development/testing/implementation of a project. A System Requirements Specifications (SRS), when written, will provide the design criteria and testing basis for a surveillance automation project.

\subsection{Scope}

The scope of this document is to address the manual surveillance data collection methods or Operator Rounds used by CHG. It will cover current methods and computer systems that receive this data. A proposed path forward with recommended improvements and suggestions for hardware and software to be used are also discussed. It will not include a determination of the validity of the data being collected in terms of need and specific collection/frequency requirements.

The intended audience for this document is the Nuclear Operations Project Services management and is intended to be a tool to determine project startup and implementation.

\subsection{Definitions}

Handheld Computer Unit (Handheld Unit): A system that is a portable computer with an integrated barcode reader that supports keyboard and barcode data input, and provides upload/download 
support for computer data. A barcode reader with attached laser scanner capable of reading code 3 of 9 is an example of such a unit.

Handheld Data Acquisition for Tank Farms (HDAT): A system used in the early 90's by Tank Farm Operations to improve manual data collection utilizing handheld computer units, barcode technology, and a database for storage and acquisition.

Nuclear Operations Project Services: Nuclear Operations Project Services is the CH2M HILL Hanford Group, Inc. that collects, reviews, distributes, and stores tank farm surveillance data. The Nuclear Operations Project Services reports early detection anomalies to management and various customers.

Operator Rounds Data Sheet: A form presently used to manually collect tank farm surveillance data.

Personal Computer Surveillance Analysis Computer System (PCSACS): Computer system that provides electronic storage of tank farm surveillance data. Mainly contains temperature, surface level readings, and interstitial liquid levels for all 177 tanks, plus some catch tanks.

Tank Monitoring and Control System (TMACS): Computerized monitoring system for sensors in the 200 area tank farms and the 100-D K Basins. Most of these data are surface level data that are received from sensors then relayed via telephone line modem to the host TMACS computer for display.

\section{Acronyms and Abbreviations}

$\begin{array}{ll}\text { CCC } & \text { Central Command \& Control Station } \\ \text { HDAT } & \text { Handheld Data Acquisition for Tank Farms } \\ \text { PCSACS } & \text { Personal Computer Surveillance Analysis Computer System } \\ \text { RWR } & \text { Routine Work Request } \\ \text { SRS } & \text { System Requirements Specifications } \\ \text { TMACS } & \text { Tank Monitoring and Control System }\end{array}$

\subsection{CURRENT BUSINESS PRACTICES}

\subsection{Data Collection}

Nuclear Operations Project Services personnel perform manual tank farm surveillance data collection or Operator Rounds. These personnel are Field Operators that are trained to enter radiation zones where the surveillance data are collected. A large percentage of tank farm surveillance data are manually collected on Operator Rounds data sheets on a daily, weekly, monthly, and quarterly basis.

Sixteen different procedures cover 192 separate Operator Rounds data sheets that support manual 
tank farm surveillance data collection and are conducted on a daily basis. In addition to these Operator Rounds data sheets, there are an additional 88 Operator Rounds data sheets that are utilized less frequently (i.e., monthly, quarterly).

During the past few years, tank farm equipment has been relabeled so that individual pieces of equipment are easily identified for reasons of identification during data collection. These labels include a barcode that can be utilized for future scanning of the equipment tag as means of data entry.

A Field Operator, travels from one piece of equipment to another and handwrites data values onto the Operator Rounds data sheets and, in some cases, calculates entries on the data sheets. Most of the surveillance data are collected in locations that are outdoors. Because most of the surveillance data collected are based on regulatory requirements, they must be collected even in severe weather and during all shifts.

After Field Operators collect the surveillance data, the Operator Rounds data sheets are signed and are sent to the Shift Supervisor for review and signature located at the Central Command \& Control (CCC) Station.

Some surveillance data are collected by TMACS. TMACS is a computerized monitoring system for sensors in the 200 area tank farms and the 100-D K Basins. Most of these data are surface level data that are received from sensors then relayed via telephone line modem to the host TMACS computer for display. TMACS is capable of receiving the following types of signals from the field.

- Temperature data from tank mounted thermocouple trees

- Liquid level indicating transmitters (ENRAF 854 LIT)

- Tank pressures

- Gas concentration and gas flows

- Discrete panel alarms from tank farm and evaporator control rooms as they become operational.

- Tank Monitoring and Control System equipment alarms

- K-Basin alarms

\subsection{Data Approval and Routing}

The CCC is the location where the Shift Operations management and other personnel perform duties relating to emergency response, tank farm monitoring, shift turnover, and Operator Rounds data sheet review, etc.

Operator Rounds data sheets go to the CCC for a first line-of-defense review, approval signatures, and to enter pertinent data into an Electronic Whiteboard that is projected onto a wall for viewing current facility status. The data for the Electronic Whiteboard are not retained, and it does not go through a validation process unless the data entry is out of range. From this point, the Operator Rounds data sheets are picked up daily by the Data Evaluation Group and reviewed for completeness, accuracy, and entry into database storage via the Personal Computer Surveillance Analysis and Computer System (PCSACS) interface. Time permitting; the Field Operator may enter data into the PCSACS. 


\subsection{Data Storage}

PCSACS is the database storage for surface levels, temperatures, interstitial liquid levels for all 177 tanks, plus some catch tanks. Some of these data are entered into the PCSACS system by the Field Operator and then are reviewed and validated by the Data Evaluation Group and some are transmitted electronically from the TMACS. If the Field Operator did not input the data to PCSACS, then Data Evaluation Group personnel enter it. After input into PCSACS, the Operator Rounds data sheets are copied and distributed to various interested parties.

Data residing in PCSACS are now available for trending, historical purposes, reporting, and tank baseline information. However, much of the data available on the Operator Rounds data sheets are not maintained in PCSACS due to the type of data. Because there are many data types that are not input into PCSACS, it is difficult to utilize this other information for any business purpose. PCSACS has different icons to represent the different functions and forms available to the users. Currently, PCSACS supports data entry, trending, reporting, and baseline information.

\subsection{Records Management}

After required signatures and entry into PCSACS the Operator Rounds data sheets are sent to the Technical Data Services Center. They are stored for five years at the facility, 278-AW, and then sent to the Records Holding Area for storage. Because of cost consideration, Operator Rounds data sheets are not scanned.

The Records Inventory and Disposition Schedule rates the Operator Rounds data sheets an " $R$ " for Record and, therefore, the retention period is 75 years, however, there is still a moratorium on Hanford documents that prevents records destruction until further notice. The requirements for records keeping are in accordance with Washington Administrative Code (WAC) 173-303-320 and WAC 173-303-380.

\subsection{PROBLEM STATEMENT}

During the interview process several primary issues were discussed, condensed, and are presented in Table 1. Primary Issues with Current Practices. The problem definition statement below summarizes today's practices that need improvements that are data collection, data storage, immediate alerting, records management, scheduling, and validation. The problem statement is:

With large volumes of required tank farm surveillance data being collected, it is difficult to manually collect, review, distribute, and manage Operator Rounds data sheets that require accuracy and completeness on a daily basis. At the time of data collection, Field Operators struggle with weather, darkness, and cumbersome 'paper' Operator Rounds data sheets that require completion once or twice a shift. Since no immediate reporting is available, it is difficult to know what equipment is deficient and what data collection has been missed or is out-of-range until a Field Operator has left the site. With so many Operator Rounds data sheets, there are transposition errors and illegible writing that make reviewing and entering the data difficult. A better method of tracking and storage of these data electronically are important to support clear, rapid presentation of data trends, reports, distribution, and rapid retrieval of past data. 


\begin{tabular}{|c|c|}
\hline \multicolumn{2}{|r|}{ Table 1. Primary Issues with Current Practices } \\
\hline Problem Category & Primary Issues \\
\hline Administration & $\begin{array}{l}\text { No computer literacy training is given to Field Operators. Some are } \\
\text { knowledgeable on how to use computers and others are not. }\end{array}$ \\
\hline Administration & $\begin{array}{l}\text { Although TMACS collects some data electronically, Field Operators are still } \\
\text { collecting those data manually in the event of a "computer malfunction". }\end{array}$ \\
\hline Data Collection & $\begin{array}{l}\text { In poor weather conditions, it is difficult to keep the Operator Rounds data } \\
\text { sheets from wrinkling and difficult to write on. }\end{array}$ \\
\hline Data Collection & $\begin{array}{l}\text { In some cases, illegible writing of the Field Operator and transcription errors } \\
\text { are difficult to read. }\end{array}$ \\
\hline $\begin{array}{l}\text { Data Collection \& } \\
\text { Immediate Alerting }\end{array}$ & $\begin{array}{l}\text { Turnover of a shift can be cumbersome sifting through Operator Rounds data } \\
\text { sheets to acknowledge a reading that needs special attention. }\end{array}$ \\
\hline $\begin{array}{l}\text { Data Collection \& } \\
\text { Immediate Alerting \& } \\
\text { Validation }\end{array}$ & $\begin{array}{l}\text { If some data points are out of range, it may be difficult to catch while in the } \\
\text { field to take a recheck. }\end{array}$ \\
\hline Data Storage & $\begin{array}{l}\text { Electronic Whiteboard needs to be manually entered daily, resulting in } \\
\text { potential transcription errors. }\end{array}$ \\
\hline Data Storage & $\begin{array}{l}\text { Entry into PCSACS can be difficult if writing is illegible or Operator Rounds } \\
\text { data sheet didn't get turned in. }\end{array}$ \\
\hline Data Storage & $\begin{array}{l}\text { PCSACS does not store the majority of the data being collected today. } \\
\text { Difficult to impossible to trend data on Operator Rounds data sheets. }\end{array}$ \\
\hline Data Storage & $\begin{array}{l}\text { Although, PCSACS does have a data input validity check process, some } \\
\text { people who perform official reporting do not use PCSACS data; rather the } \\
\text { Operator Rounds data sheets are used. }\end{array}$ \\
\hline $\begin{array}{c}\text { Records } \\
\text { Management }\end{array}$ & $\begin{array}{l}\text { WAC requirement states that the person taking the reading must sign the } \\
\text { Operator Rounds data sheet. }\end{array}$ \\
\hline Scheduling & $\begin{array}{l}\text { Efforts are doubled; a } 24 \text {-hour time period is never left unmonitored. } \\
\text { A 24-hour reading is taken twice a day. }\end{array}$ \\
\hline Validation & $\begin{array}{l}\text { With such large volumes of data being collected, it is difficult to catch all } \\
\text { Technical Safety Requirements as well as other requirements. }\end{array}$ \\
\hline Validation & $\begin{array}{l}\text { No immediate reporting available on what data was missed, so operators do } \\
\text { not know that something has been missed until after they have left the site. }\end{array}$ \\
\hline Validation & $\begin{array}{l}\text { Out-of-specification readings are problems. Would like to track "red circles" } \\
\text { to completion (Equipment Deficiency List). }\end{array}$ \\
\hline $\begin{array}{l}\text { Validation } \\
\& \text { Scheduling }\end{array}$ & $\begin{array}{l}\text { If the reading is out of tolerance, a Routine Work Request (RWR), Repair } \\
\text { Work Request, or a Corrective Action is generated depending on the } \\
\text { circumstances. These are difficult to track, so duplicates are created } \\
\text { particularly for items that are checked once per shift, since there is a two-day } \\
\text { lag between initiating a RWR and it even getting a number. } \\
\text { Automatic RWR generation would be useful. }\end{array}$ \\
\hline Validati & $\begin{array}{l}\text { If calculations are required, calculation errors may occur with much time } \\
\text { spent correcting data. }\end{array}$ \\
\hline
\end{tabular}




\subsection{PROPOSED BUSINESS PRACTICES}

\subsection{Overview}

In review of the primary issues and of the existing practices, it is recommended that handheld computer units, barcodes located at the equipment, and a database used for storage and reporting be utilized for Operator Rounds and the current Operator Rounds data sheets be used as backup.

Each primary issues listed by category in Table 1. Primary Issues with Current Practices would be met by this proposed method. Below are the seven categories and brief discussions on how the proposed method would be an opportunity. Benefits are discussed in the further sections.

- Administration:

The opportunity is to provide data to management quickly in order to improve decisionmaking and to increase operational efficiency. Computer literacy training and redundant data collection are in need of management discussion and decisions.

- Data Collection:

The opportunity is to use electronic data transfers rather than data entry and reduce or eliminate errors by improving the method of collecting data.

- Data Storage:

The opportunity is to have electronic data storage that allows rapid presentation of data and trends and eliminates searching for data through paper Operator Rounds data sheets.

- Immediate Alerting:

Opportunity is to have on-the-spot baseline criteria data checking that enables notification more timely to appropriate personnel. Immediate alerting to the Field Operator will reduce rechecks.

- Records Management:

Opportunity is to use database reporting to allow data review and approval on-line; a report printed and signed for purposes of the hardcopy long-term storage requirement.

- Scheduling:

Opportunity is to ensure daily/weekly/monthly/quarterly data collection schedules and tank farm routes and various requirements associated with timeliness are being met.

- Validation:

Opportunity is to validate data at the time of capture by ensuring calculations, baseline criteria, technical safety requirements, and daily routes are correctly entered. 


\subsection{Concept}

The overall concept is the Field Operator will no longer transcribe surveillance data onto Operator Rounds data sheets. A Field Operator will enter a tank farm, scan the barcode equipment label with a handheld computer unit that will identify the equipment and then prompt for a data value. A Field Operator will have the opportunity to validate all readings have been taken prior to leaving an area. The handheld computer unit will also perform baseline criteria checks and ensure tank farm routes are followed during the time of data collection. In addition to baseline criteria checks, the handheld computer unit will also calculate formulas as needed.

After a Field Operator completes their Operator Rounds in a given tank farm, they return to the $\mathrm{CCC}$ or local office and the handheld computer unit is placed into a communications cradle for data downloading to a database for review, reporting, distribution, and storage. The communications cradle will also act as an uploading device to get information for a Field Operator's tank farm route, baseline updates for baseline criteria checks, and procedural information on how to perform data collection.

\subsection{Recommendations}

The recommended path forward is in phases due to the number of data types collected. The Integrated Environment, Safety and Health Management System (ISMS) guiding principle of worker involvement warrants Field Operators participation in all aspects of the project. The overall infrastructure to support the end product would be accomplished in four phases with each phase providing an application deliverable. The interest of this project is to ensure that the overall application is expandable and adaptable to support future tank farm infrastructure, as various upcoming projects are moving towards implementing programmable logic controllers. Below the phases are discussed in detail and Appendix A - Lifecycle Phases is referenced.

The recommended path forward for hardware is to complete the SRS and review the hardware in Appendix B - Hardware, for possible hardware candidates. A single, upgradeable handheld computer unit that could potentially work for each of these phases is preferred. A Requirements Matrix, the product, and the hardware specifications are identified.

\subsubsection{Electronic Data Capture (Phase 1)}

Electronic Data Capture includes barcode technology, handheld computer units with the ability to download Operator Rounds information, equipment lists, baseline criteria, and where appropriate, procedures, and an interim database for trending, reporting, and storage without the full use of the intranet or HLAN. See Appendix A - Lifecycle Phases, Electronic Data Capture.

The scope of Electronic Data Capture needs to be determined and possibilities include:

1) Automate tank farms that presently have the most data sheets (AP and AW Tank Farms).

2) Pilot a tank farm that is presently involved in the saltwell pumping efforts.

3) Rollout expansion in all tank farms and implement a tank farm one at a time. 
Features and benefits available from Electronic Data Capture are:

1) Barcode scanning to improve the ease and accuracy of data collection in the field by not requiring operators to enter data on Operator Rounds data sheets.

2) Printed reports of data collected for signature and storage to reduce the number of Operator Rounds data sheets stored for Records Management purposes.

3) On screen output notifying Field Operator of out-of- range readings allowing on-the-spot rechecks and validation.

4) Electronic calculation of formulas to reduce human error and save time.

5) Notification to Field Operator on missed readings prior to departing the area preventing having to return and perform rechecks and potentially reducing the frequency of Operator Rounds performed.

6) Data stored in a database provides the ability to analyze data trends and predict equipment failure and/or equipment replacement requirements.

7) Automatic data transfer to the Shift Office's Electronic Whiteboard without requiring data entry, thus reducing errors and improving timeliness of data available in Shift Office, PCSACS, and other systems.

8) Automatic flagging of abnormal or out-of-tolerance readings to identify potential problems to the Shift Office on a timely basis.

9) Data stored in a database can be retrieved electronically, improving the availability of data versus the Operator Rounds data sheets filed in at the Technical Data Services Center.

\subsubsection{Surveillance Application (Phase 2)}

Adding a Surveillance Application includes the above with a permanent Surveillance Application database for trending, reporting, and storage. The Surveillance Application would also add the capability to plan and schedule routes for Operator Rounds. The Surveillance Application will be selected based on the System Requirements Specification and an Alternatives Analysis based on the SRS. See Appendix A - Lifecycle Phases, Surveillance Application.

Features and benefits available from Surveillance Application are:

1) Decrease missed Operator Rounds and/or readings by having predefined routes generated by the Surveillance Application.

2) Data stored in the Surveillance Application can be used to for trending, analysis, and reporting, providing the basis of determining surveillance requirements and frequency to meet regulatory and Technical Safety Requirements.

3) Data stored in system may be used to reduce hard copy record keeping requirements by utilizing system security and allowing secured, electronic signatures.

4) Improved data trending and analysis allows improved predictive equipment management (See 6 in Electronic Data Capture).

5) Route planning and tracking ensures proper data collection and frequency.

6) Improved data sharing with other applications such as PCSACS, the Electronic Whiteboard, and other systems. 
The permanent Surveillance Application database to be used for review and storage is to be determined. At this time, PCSACS contains several data types supporting tank farm surveillance data. However, the current 192 Operator Rounds data sheets contain over 50 data types. These data are collected and reviewed on a daily basis, therefore, trending and reporting is essential. Although, PCSACS is a likely candidate to expand, it may be costly, as this would include database customization to support data forms, special reports, and an interface protocol to the handheld computer unit's communications cradle to be used for downloading.

Another likely candidate is a commercial product called Maximo ${ }^{\mathrm{TM} \mathrm{M}^{1}}$. Just recently, an Alternatives Analysis and an SRS was completed for Work Management to support a Business Management request to recommend commercial-off-the-shelf software that would support CHG's business infrastructure. If $\mathrm{CHG}$ management decides to implement Maximo, then this becomes a stronger candidate to support the database storage as Maximo has software functionality that allows tailoring of forms and database tables with minimal effort.

\subsubsection{Wireless \& Work Management Integration (Phase 3)}

Wireless Communication \& Work Management Integration includes the above along with handheld computer units with wireless capabilities and an interface to the Work Management System. Use of wireless technology will enable real-time updating of the permanent Surveillance Application database. The interface to a Work Management System will allow the initiation of work based on the readings collected during Operator Rounds as well as the ability to determine the status of the work request. See Appendix A - Lifecycle Phases, Wireless Communication and Work Management Integration.

Features and benefits of Wireless Communication and Work Management Integration are:

1) Wireless communication decreases time between data collection and availability, which will improve the ability to respond to out-of-range readings.

2) Eliminates the need for the handheld computer unit's communications cradle for downloading.

3) Ability to automatically initiate work requests decreases elapsed time to perform work.

4) Ability to utilize readings to conduct preventative maintenance minimizes breakdowns and unsafe conditions.

5) Ability to link work requests to out-of-range readings improves resolution tracking.

6) Tank farm surveillance data can be utilized to improve job planning.

1 Maximo is a product from PSDI, Inc. 


\subsubsection{Future Data Capture (Phase 4)}

Additional Future Data Capture includes expansion to support other data collection activities not necessarily in the tank farms. Facility inspections and custodial rounds are examples of other data collection methods that require use of Operator Rounds data sheets and signatures.

Features and benefits of Future Data Capture are:

1) Extending the Surveillance Application system to cover lock and tag conditions will increase the timeliness of information available to the planning, maintenance, and engineering organizations.

2) Incorporating other surveillance activities into Operator Rounds will reduce time spent in controlled areas, overall.

3) Tracking of other conditions improves overall safety and operations.

\subsection{Deliverables}

Basic deliverables for the four phases are listed below. This list may be modified depending on requirements identified in the System Requirements Specifications.

\begin{tabular}{|l|l|l|l|l|}
\hline Deliverable & $\begin{array}{l}\text { Electronic Data } \\
\text { Capture }\end{array}$ & $\begin{array}{l}\text { Surveillance } \\
\text { Application }\end{array}$ & $\begin{array}{l}\text { Wireless and Work } \\
\text { Management }\end{array}$ & $\begin{array}{l}\text { Future Data } \\
\text { Capture }\end{array}$ \\
\hline $\begin{array}{l}\text { System Requirements } \\
\text { Specifications }\end{array}$ & Yes & Yes & Update & Update \\
\hline System Design Description & Yes & Yes & Update & Update \\
\hline Computer Program(s) & Yes & Yes & Update & Update \\
\hline System Testing & Yes & Yes & Yes & Yes \\
\hline $\begin{array}{l}\text { Software Configuration } \\
\text { Management Plan }\end{array}$ & Yes & Update & Update & Update \\
\hline Operational Version & Yes & Yes & Yes & (new rounds only) \\
\hline
\end{tabular}




\subsection{APPENDIX A-LIFECYCLE PHASES}

(This page left intentionally blank). 


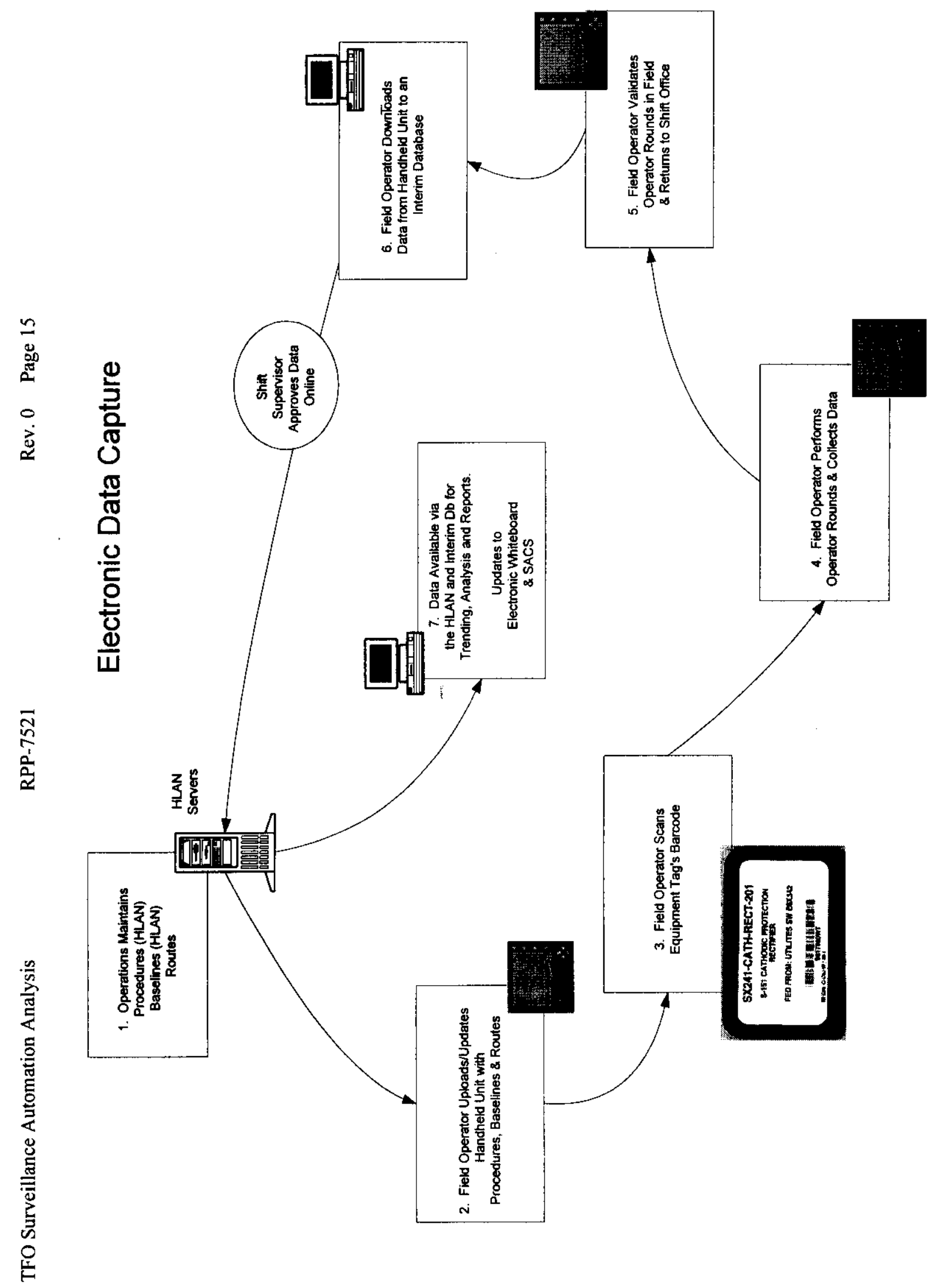




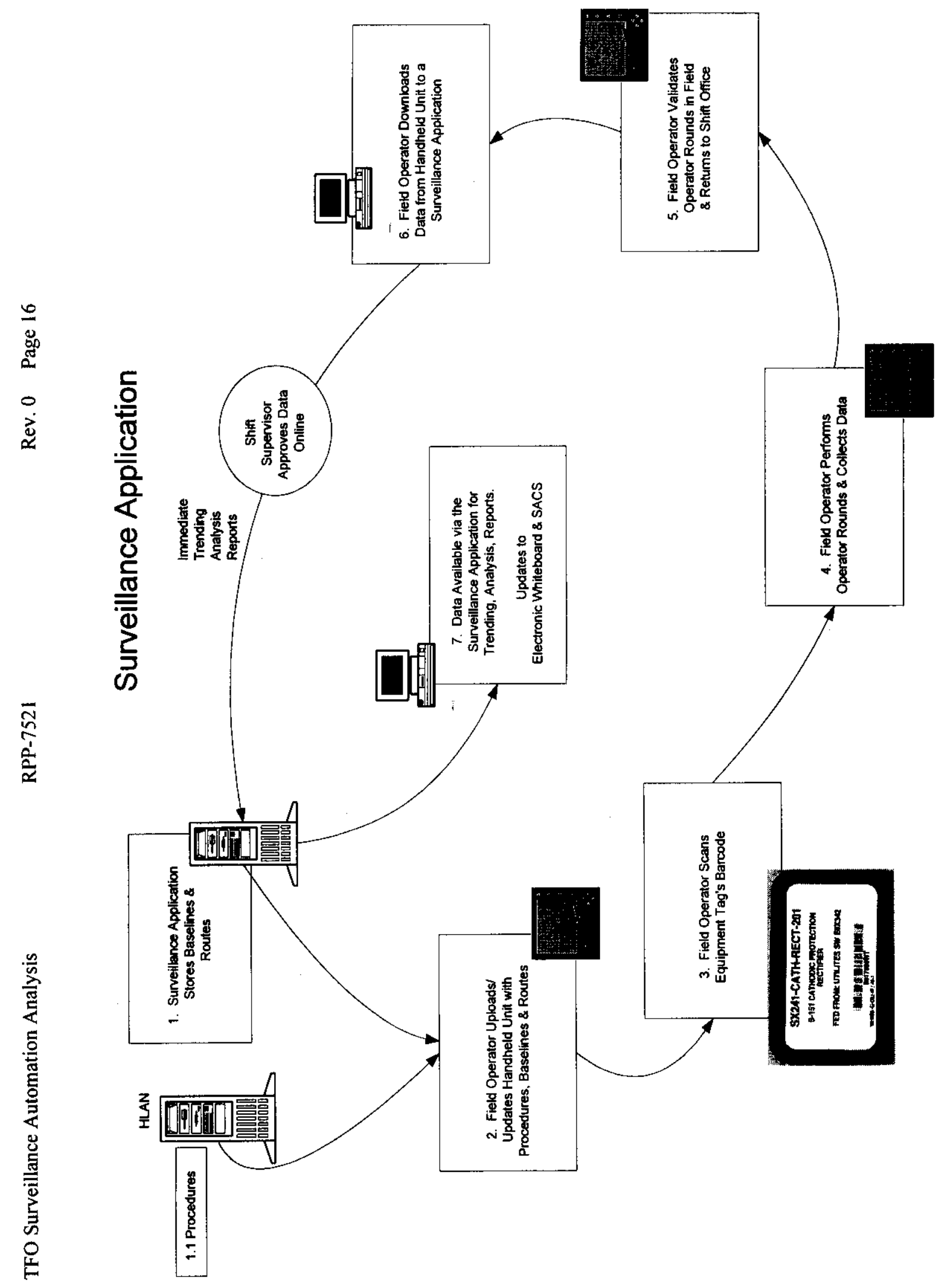




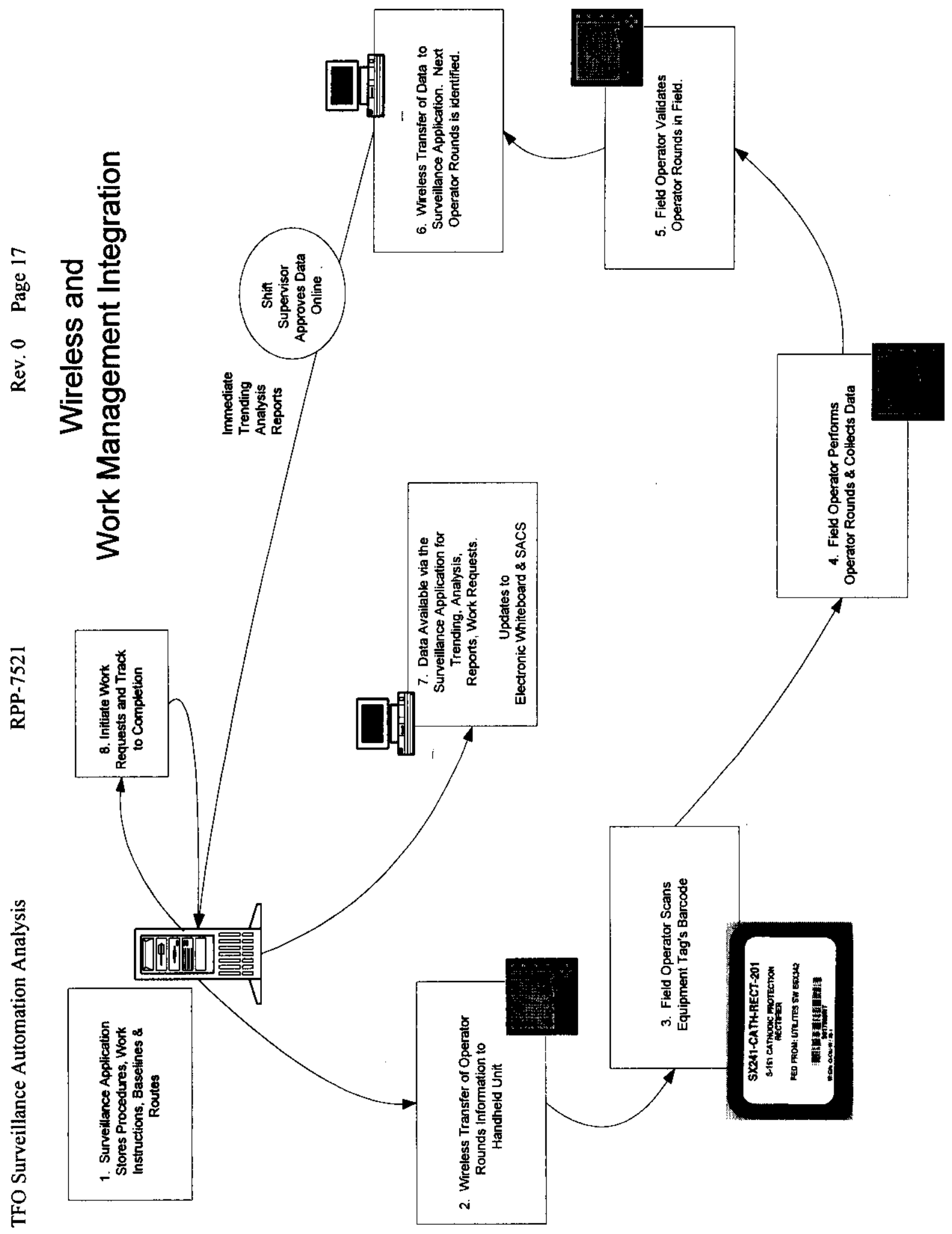




\subsection{APPENDIX B - HARDWARE}

(This page left intentionally blank). 


\section{Handheld Computer Units Candidate Devices}

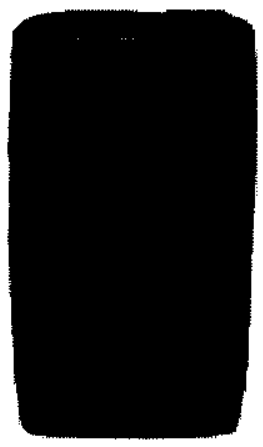

Intermec 600 Series

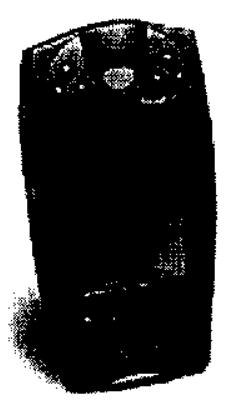

Symbol PPT2700

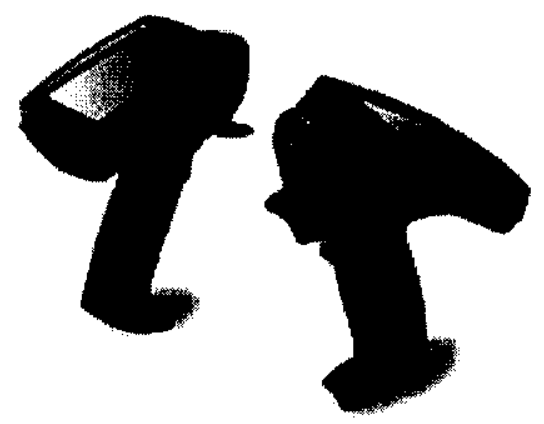

Symbol PDT 7200

The three handheld computer units displayed above would be feasible to support the four recommended phases to improve manual tank farm surveillance data collection. Each handheld computer unit is lightweight, has a high battery life performance (depending on use), touch screen input, can withstand extreme heat and cold, supports bar code scanning, has a backlit display, Windows CE operating environment, and has enough memory to support current Operator Rounds. The two Symbol devices can support wireless communications, intranet, and email. Each handheld computer unit also has a hands-free carrying case.

The three handheld computer units displayed meet the minimum requirements (with the exception of battery life) set forth in the initial specifications. The battery life performance is highly dependant on characteristics of use. Scanning is the usual measure manufacturers mention. These handheld computer units are all rated to support several hundred scans per 8-hour period. Other use options will also impact battery life; for example, wireless LAN use is expected to negatively impact battery life.

All three of these devices offer the Windows CE operating environment, and, therefore, benefit from available skill sets, as well as rich development tools. This feature was weighted heavily in order to offer ease of integration and support of future system enhancements, as well as future hardware upgrades. The Windows CE operating environment simplifies standard methods of communications with other networked computers.

All three devices offer touch screen input via a stylus or touch to enhance operation by individuals dressed in protective clothing or protection from the elements. The display / touch screen is operates under program control, but they do not support cursive data entry. 
The Symbol PPT 2700 and the Symbol PDT 7200 offer wireless LAN operation. Once connected to the LAN, Intranet / Internet connectivity can be established. If equipped for wireless operation, they will also support paging. These two systems also include a standard PCMCIA expansion slot. This slot can be used for a variety of purposes, such as FLASH memory expansion or cellular modem.

Other desirable characteristics that are not currently supported by these handheld computer units are Electronic Signature and Global Positioning System; however, future developments may support these technologies. The two tables below detail how the handheld computer units met both mandatory and desired requirements.

\section{Mandatory Requirements}

Weighs less than 2 Lbs.

Drop Test -4 feet onto concrete

No air intake

Temperature operating range $-10^{\circ}$ to $122^{\circ}$

Numeric data entry (On screen or keypad)

Alpha data entry (On screen or keypad)

Lighted display

Memory

Processor

Water proof or water resistant for outdoor use Hands free carrying case

Bar code scanning

Battery life 12 hours

Battery swapping

Screen size 5"X 7" or less

(overall 8" X 11" max)

Data upload / download to Windows based environment

\begin{tabular}{|c|c|c|}
\hline \multirow{2}{*}{$\begin{array}{l}600 \text { Series } \\
\text { (Intermec) } \\
11 \mathrm{Oz} . \\
\text { Yes }\end{array}$} & $\begin{array}{l}\text { PPT 2700 } \\
\text { (Symbol) } \\
11.8 \mathrm{Oz} .\end{array}$ & $\begin{array}{l}\text { PDT } 7200 \\
\text { (Symbol) } \\
21 \mathrm{Oz} .\end{array}$ \\
\hline & $\begin{array}{l}4 / 1.2 \mathrm{~m} \text { to } \\
\text { concrete }\end{array}$ & $\begin{array}{l}\text { Multiple } 4^{\prime} / 1.2 \mathrm{~m} \\
\text { drops to } \\
\text { concrete/Multiple } \\
6^{\prime} / 1.8 \mathrm{~m} \text { drops } \\
\text { with optional } \\
\text { rubber boot }\end{array}$ \\
\hline $\begin{array}{l}\text { Yes } \\
-4^{\circ} \text { to } 140^{\circ} \\
\text { Screen / } \\
\text { keypad }\end{array}$ & $\begin{array}{l}\text { Yes } \\
-4^{0} \text { to } 122^{0} \\
\text { Screen }\end{array}$ & $\begin{array}{l}\text { Yes } \\
-4^{0} \text { to } 122^{0} \\
\text { Screen }\end{array}$ \\
\hline Screen & Screen & Screen \\
\hline Yes & Yes & Yes \\
\hline 8-32MB + up & $16 \mathrm{MB}+12$ & $4-16 \mathrm{MB}+$ up \\
\hline to $40 \mathrm{MB}$ & MB Flash & $32 \mathrm{MB}$ of Flash \\
\hline $\begin{array}{l}\text { Flash } \\
\text { Memory }\end{array}$ & Memory & Memory \\
\hline 486 & $\begin{array}{l}\text { NEC Vr4181 } \\
\text { (MIPS) }\end{array}$ & 486 \\
\hline Yes & Yes & Yes \\
\hline Yes (option) & Yes (option) & Yes (option) \\
\hline Yes (option) & Yes & Yes \\
\hline $\begin{array}{l}\text { 8-10 hours } \\
\text { (application } \\
\text { dependent) }\end{array}$ & Variable & Variable \\
\hline Unknown & Unknown & 5 Minutes \\
\hline $\begin{array}{l}3 " X 9 " \\
\text { overall }\end{array}$ & $\begin{array}{l}7 " \times 3.6 " \\
\text { overall }\end{array}$ & 7.8" X 5.9" \\
\hline Yes & Yes & Yes \\
\hline
\end{tabular}




\section{Desirable Features}

Wireless Intranet

Wireless Communication

Global Positioning System

Electronic Signature

Email

Cursive writing recognition

Touch screen entry

\begin{tabular}{|c|c|c|}
\hline $\begin{array}{l}600 \text { Series } \\
\text { (Intermec) }\end{array}$ & $\begin{array}{l}\text { PPT } 2700 \\
\text { (Symbol) }\end{array}$ & $\begin{array}{l}\text { PDT } 7200 \\
\text { (Symbol) }\end{array}$ \\
\hline No & Yes & Yes \\
\hline No & $\begin{array}{l}\text { Yes wireless } \\
\text { LAN }\end{array}$ & $\begin{array}{l}\text { Yes wireless } \\
\text { LAN }\end{array}$ \\
\hline No & No & No \\
\hline No & No & No \\
\hline No & $\begin{array}{l}\text { Wireless } \\
\text { LAN* }^{*}\end{array}$ & $\begin{array}{l}\text { Wireless } \\
\text { LAN* }\end{array}$ \\
\hline No & No & No \\
\hline Yes & Yes & Yes \\
\hline
\end{tabular}

*While email is not specifically discussed manufacturers, platform flexibility and wireless LAN capability implies it is plausible. The benefit of email would have to be weighed against benefit of other uses of resources consumed by the email client.

\section{Vendor Web Page Addresses (for additional product information):}

Intermec 600 Series--http://corp.intermec.com/products/600spec.htm PPT 2700--http://www.symbol.com/products/mobile_computers/mobile_ppc_ppt2700.html PDT 7200--http://www.symbol.com/products/mobile_computers/mobile_pen_touch_pdt_7200.html 